\title{
Serosurvey of human T cell lymphotropic virus I/II among blood donors in Gombe (Nigeria)
}

\author{
Mohammed Mohammed Manga, Adeola Fowotade, Saleh Yuguda, \\ Girei Ahmed Iya, Mohammed Yahaya, Yakubu Munkaila Sheriff, Omoruyi \\ Ewean Chukwuma, Ibrahim Musa Yola, Rasheed Ajani Bakare
}

\begin{abstract}
Aim: This study was carried out to determine the prevalence of human $T$ cell lymphotropic virus I/II (HTLV I/II) among blood donors at the Federal Teaching Hospital Gombe (FTHG), North-eastern, Nigeria. Methods: A total of 355
\end{abstract}

Mohammed Mohammed Manga ${ }^{1}$, Adeola Fowotade ${ }^{2}$, Saleh Yuguda ${ }^{3}$, Girei Ahmed lya ${ }^{4}$, Mohammed Yahaya ${ }^{5}$, Yakubu Munkaila Sheriff ${ }^{6}$, Omoruyi Ewean Chukwuma ${ }^{7}$, Ibrahim Musa Yola ${ }^{8}$, Rasheed Ajani Bakare ${ }^{9}$

Affiliations: ${ }^{1} \mathrm{MBBS}$, Lecturer and Consultant, Department of Medical Microbiology and Immunology, Federal Teaching Hospital Gombe, Gombe state Nigeria; ${ }^{2}$ MBBS, MSc Medical Virology, Lecturer and Consultant, Department of Medical Microbiology and Parasitology, University College Hospital Ibadan, Oyo state Nigeria; ${ }^{3} \mathrm{MBBS}$, Lecturer and Consultant, Department of Haematology, Federal Teaching Hospital Gombe, Gombe state Nigeria; ${ }^{4}$ MBBS, Consultant, Department of Haematology, Federal Teaching Hospital Gombe, Gombe state Nigeria; ${ }^{5} \mathrm{MBBS}$, Lecturer and Consultant, Department of Medical Microbiology and Parasitology, Usmanu Danfodio Univeristy Sokoto, Sokoto state Nigeria; ${ }^{6} \mathrm{BSc}$, Assistant Director Laboratory Services, Department of Haematology, Federal Teaching Hospital Gombe, Gombe state Nigeria; ${ }^{7} \mathrm{BSc}$, Institute of Child Health, College of Medicine University of Ibadan, Oyo state Nigeria; ${ }^{8}$ MBBS, Lecturer and Consultant, Department of Medicine, Federal Teaching Hospital Gombe, Gombe state Nigeria; ${ }^{9} \mathrm{MBBS}$, Professor and Consultant, Department of Medical Microbiology and Parasitology, University College Hospital Ibadan, Oyo State Nigeria.

Corresponding Author: Dr Mohammed M. Manga, Department of Medical Microbiology and Immunology, Federal Teaching Hospital, Ashaka road, PMB 037, Gombe, Gombe State Nigeria; Email: mangamuhammad@yahoo.co.uk, drmmanga@gmail.com

Received: 05 March 2016

Accepted: 14 April 2016

Published: 09 May 2016 blood donors were recruited at the hematology department of FTHG for a hospital based crosssectional study and were screened/confirmed for HTLV I/II by ELISA and western blot methods. Results: Seroprevalence of HTLV I/II among the 355 participants with mean age of 30.77 years ( \pm 8.27) was $6.5 \%$ on screening with ELISA but confirmed to be o\% by western blot. Majority were males, 352 (99.2\%) and mostly (45.9\%) between 21-30 years of age. Donors for family replacements predominated $(85.1 \%)$ with more than half (58.6\%) being first time blood donors. Conclusion: This study reveals the absence of HTLV I/II among blood donors in Gombe Northeastern Nigeria. It also highlights the possibility of false positivity in some of the reported prevalence of HTLV I and II from some parts of Nigeria that were based on screening tests only. The importance of confirmatory testing in all research works on HTLV (including HTLV 3 and HTLV 4) is further strengthened with this study. There is however the need for a larger study and the use of molecular diagnostics to reconfirm this assertion.

Keywords: Blood donors, Gombe, Human $\mathbf{T}$ cell lymphotropic virus I/II (HTLV I/II), Nigeria, $T$ cell

\section{How to cite this article}

Manga MM, Fowotade A, Yuguda S, Iya GA, Yahaya M, Sheriff YM, Chukwuma OE, Yola IM, Bakare RA. Serosurvey of human T cell lymphotropic virus I/II among blood donors in Gombe (Nigeria). Int J Blood Transfus Immunohematol 2016;6:12-19.

Article ID: 100024IJBTIMM2016 


\section{INTRODUCTION}

Human T cell lymphotropic virus I (HTLV-I) is the first human retrovirus to be discovered and has continued to be an important transfusion transmissible infection (TTI) especially in highly endemic regions such as the subSaharan Africa [1]. The virus has been associated with several diseases including adult T cell leukemia (ATL), tropical spastic paraparesis, HTLV-I uveitis and HTLV-I associated infective dermatitis $[2,3]$. The ATL develops only in HTLV-I infected individuals and all ATL cells contain integrated HTLV-I provirus [4]. Geographical areas with high incidence of ATL patients correspond closely with those of high incidence of HTLV-I carriers [5]. However, HTLV-II has not been causally linked to human malignancy but may be associated with lymphocytosis, increased risk of developing inflammatory neuropathies and infectious diseases [6].

Blood safety remains an important public health concern in Africa as morbidity and mortality from unsafe blood continues to adversely impact on populations [7]. Human $\mathrm{T}$ cell lymphotropic virus has been considered to be currently one of the greatest concerns threatening health of blood recipients in some endemic areas [8]. Intravenous exposure to contaminated blood or blood products is the most efficient mode of HTLV-I transmission with up to $63.4 \%$ seroconversion rate reported in Japan [3, 9]. Additionally, blood transfusion related HTLV associated diseases develop more rapidly than with other means of transmission [10].

Immunosuppression increases the risk of HTLV transmission with shorter latency period when compared to healthy carriers [11]. The HIV pandemic has led to an upsurge in the number of immunosuppressed patients, thus supporting the need for pre-transfusion screening for TTIs including HTLV. This is more important in highly endemic regions, including Nigeria. HTLV-I/HIV-1 co-infection is associated with severe clinical manifestations of HIV and worsening of the immunosuppressive status of the patient [12]. In Africa, this becomes a major concern due to the high burden of HIV infection in the region [13].

Routine screening for antibodies to HTLV-I and HTLV-II has been instituted in blood banks in many countries including Japan, USA, Canada, the Caribbean, France, Brazil and Australia [2, 3]. Presently in African countries Nigeria inclusive, there is no routine screening programme for HTLV among blood donors [14, 15]. Prevalence studies on HTLV from some regions of Nigeria do exist. However, there is paucity of data on the burden of this virus from other parts of Nigeria especially the north-eastern region.
This current discourse is aimed at establishing the prevalence of HTLV I/II among blood donors in Gombe, Nigeria.

\section{MATERIALS AND METHODS}

\section{STUDY POPULATION}

Healthy blood donors presenting at the blood bank unit of the Haematology department Federal Teaching Hospital Gombe (FTHG) who met the inclusion criteria were recruited after written informed consent was sought and obtained. The inclusion criterion was: (i) all consenting apparently healthy blood donors between the ages of 18 and 65 years. The exclusion criteria were: (i) refusal to give consent for participation in the study, (ii) individuals not eligible to donate blood. (Supplementary Table 1: Criteria for eligibility to donate blood. Available online at the journal's website).

Ethical clearance and approval was obtained from the research and ethics committee of the FTHG for the study. Handling, storage and disposal of the specimens was strictly based on sound ethical principles.

\section{STUDY DESIGN}

This hospital-based cross-sectional study was done using enzyme linked immunosorbent assay (ELISA) and Western Blot (WB) to detect and confirm HTLV I/II among apparently healthy blood donors.

Sample size was determined using the Fisher's formula as 333 based on the HTLV prevalence of 3.6\% [16] among blood-donors from northern Nigeria. This was readjusted to 366 by adding $10 \%$ of the calculated figure to make room for attrition. Three hundred and sixty-six donors were recruited for the study but 355 were analysed as 11 specimens were found to be unsuitable for the study. A semi-structured questionnaire was administered to each participant.

\section{LABORATORY METHODS}

\section{Specimen collection and storage}

Five milliliter of venous blood was collected aseptically from all consenting participants into an EDTA specimen container with immediate separation of plasma from other components. The plasma component was then stored at $-20^{\circ} \mathrm{C}$.

\section{Screening and confirmation}

HTLV I/II screening was done using HTLV I \& II Ab version ULTRA EIA assay kit by DIA.PRO diagnostic bioprobes Milano Italy [17]. All positive samples from the ELISA were confirmed using WB with HTLV BLOT Version 2.4 by MP Biomedicals Asia Pacific Pte. Ltd. (formerly Genelabs Diagnostics Pte. Ltd.) Singapore [18]. 
All tests and result interpretations were done following the manufacturers' guidelines.

\section{DATA ANALYSIS}

Descriptive and inferential statistical data analysis was done using Statistical package for the social sciences version 22 (SPSS Inc., Illinois, USA).

\section{RESULTS}

\section{Age and sex distribution of the partici- pants}

A total of 366 blood donors were recruited but 355 were studied. Their age range was 18 to 58 years with a mean of $30.77( \pm 8.27)$ years. Donors between 21 and 30 years of age constituted the majority with $45.9 \%$ (163) while those above 40 years with $12.7 \%$ (45) were the least among the study population, (Figure 1). Male donors were predominant as they accounted for $99.2 \%$ (352) of the respondents with females constituting only $0.8 \%$ (3).

\section{Behavioral characteristics of the blood donors}

Behavioral characteristics of the donors are presented in Table 1. Virtually all (99.7\%) the respondents never had any blood transfusion as only one (0.3\%) had a history of blood transfusion. Most of the blood donors (86.4\%) reported not having multiple sexual partners and only 48 (13.6\%) had more than one sexual partner. First time blood donors were more and constituted $58.6 \%$ (208) of the respondents as against 147 (41.4\%) who had history of prior blood donation. Majority of the donations were made for family replacement purposes $(85.1 \%)$, followed by voluntary donations (14.6\%), while donations for commercial purposes were the least frequent at $0.3 \%$.

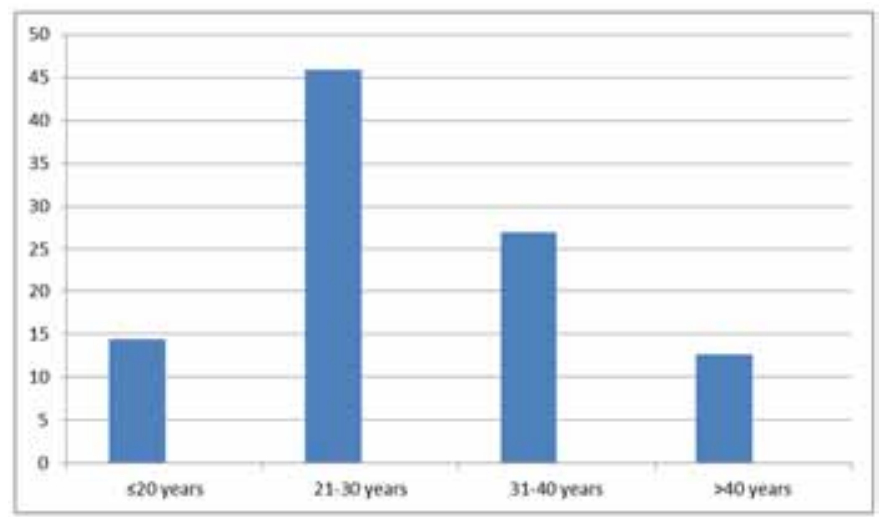

Figure 1: Percentage proportion of different age groups among the blood donors

Age groups $\leq 20$ years, 21-30 years, $31-40$ years and $>40$ years constituted $14.4 \%, 45.9 \%, 27.0 \%$ and $12.7 \%$ respectively.

\section{Prevalence of HTLV I and II among the blood donors}

The prevalence of HTLV I and II based on ELISA test alone was $6.5 \%(n=23)$. None of the respondents had an indeterminate result and all the positive specimens from ELISA were confirmed negative by western blot (Table 2).

Table 1: Behavioral characteristics of the blood donors

\begin{tabular}{|c|c|c|}
\hline Variable & Frequency & $\%$ \\
\hline \multicolumn{3}{|c|}{ Multiple sexual partners } \\
\hline Yes & 48 & 13.6 \\
\hline No & 306 & 86.4 \\
\hline \multicolumn{3}{|c|}{$\begin{array}{l}\text { Number of multiple sexual } \\
\text { partners }\end{array}$} \\
\hline Two & 36 & 75.0 \\
\hline Three & 09 & 18.8 \\
\hline More than three & 03 & 6.3 \\
\hline \multicolumn{3}{|c|}{ History of blood transfusion } \\
\hline Yes & 01 & 0.3 \\
\hline No & 354 & 99.7 \\
\hline \multicolumn{3}{|c|}{ Previous blood donation } \\
\hline Yes & 147 & 41.4 \\
\hline No & 208 & 58.6 \\
\hline \multicolumn{3}{|c|}{$\begin{array}{l}\text { Number of previous blood } \\
\text { donations }\end{array}$} \\
\hline One & 97 & 66.0 \\
\hline Two & 19 & 12.9 \\
\hline Three & 09 & 6.1 \\
\hline Four & 04 & 2.7 \\
\hline More than four & 18 & 12.2 \\
\hline \multicolumn{3}{|l|}{ Purpose of donation } \\
\hline Voluntary & 52 & 14.6 \\
\hline Family replacement & 302 & 85.1 \\
\hline Commercial & 01 & 0.3 \\
\hline \multicolumn{3}{|l|}{ Drug Abuse } \\
\hline Yes & 03 & 0.8 \\
\hline No & 352 & 99.2 \\
\hline Total & 355 & 100 \\
\hline
\end{tabular}

Table 2: Prevalence of HTLV I/II among the blood donors

\begin{tabular}{lll} 
Variable & Frequency & $\%$ \\
HTLV I/II (ELISA) & & \\
Positive & 23 & 6.5 \\
Negative & 331 & 93.5 \\
Indeterminate & oo & 00 \\
HTLV I \& II (WESTERN BLOT) & & \\
Positive & oo & 0.0 \\
Negative & 23 & 100 \\
Indeterminate & oo & oo \\
Total & 355 & 100 \\
\hline
\end{tabular}

Abbreviations: HTLV Human T cell Lymphotropic Virus, ELISA Enzyme Linked Immunosorbent Assay 


\section{DISCUSSION}

This study is about the first to be reported from any part of North-eastern Nigeria. Three hundred and fiftyfive (355) blood donors in FTHG were studied and a seroprevalence of $6.5 \%$ was obtained based on ELISA which was confirmed to be $0 \%$ following western blot testing.

A recent study from Enugu in South-eastern Nigeria also reported a similar zero (o\%) prevalence among prospective blood donors [19]. Some other Nigerian studies have also reported low prevalence of HTLV among different population groups [20, 21]. Low prevalence rates have also been reported from some African countries with 0.16\% in Dakar, Senegal and 2.3\% in Guinea Bissau $[22,23]$. Although more than half of the studies on HTLV from Nigeria did not perform any confirmatory test, higher prevalence rates among certain high risk groups in Nigeria are not unusual [14, 24]. Geographical variations in prevalence of HTLV based on ethnic/socio-cultural and environmental differences from different parts of the world has been well documented [1]. Nigeria is both geographically and socio-culturally diverse. It is therefore not surprising to find $0 \%$ prevalence from a region of Nigeria that has hitherto never reported any study on HTLV or HTLV-associated diseases.

False positive results with enzyme immunoassays (EIAs) for antibodies to HTLV-I/II have led to the unnecessary deferral of tens of thousands of potential blood donors even in developed countries [25]. HTLV ELISA has shown very high $(60-80 \%$ among blood donors) false-positive rates in areas of low prevalence and only confirmatory testing rules out actual HTLV infection [26]. However, virtually no confirmatory testing has ever been reported from northern Nigeria especially the North-eastern region. High level of false positive ELISA for HTLV from some parts of the world (e.g., 29.2\% in Caracas [27] and $100 \%$ in Turkey [28]) could indicate that carrying out this study on larger sample size may reveal a similar prevalence from north-eastern Nigeria.

Cross-reactivity with plasmodium falciparum is one of the most suggested possible explanations for false positive HTLV ELISA especially in malaria endemic areas (like Nigeria) [29, 30]. False-positive HTLV EIA results with negative confirmatory Western blot test results have also been associated with many factors, such as influenza vaccine, severe acute respiratory syndrome, some bacterial infections, autoimmune disorders and multiple pregnancies [31-33]. Srivastava et al. demonstrated that both ELISA and Western blot assay have limitations for HTLV-I antibody detection in an ATL non-endemic population based on the many false positives obtained by ELISA, and weak/indeterminate reaction (mostly p19 band) on Western blotting [34]. Although none was observed in this study, indeterminate results had been reported to be a source of false positive ELISA tests [14, 34].

HTLV-3 and HTLV-4 which share similar genomic organization to HTLV-I and HTLV-II, and weak but reproducible cross-reactivity with indeterminate results in western blot may be a source of false positive results in serologic assays employing HTLV-I and HTLV-II antigens [35]. With up to $60 \%$ similarity in identity, HTLV-3 and HTLV-4 has been incorrectly identified as either HTLV-I or HTLV-II serologically [36, 37]. Using the same HTLV blot 2.4 as this study, both negative and sero-indeterminate results were recorded before being confirmed as HTLV-3 [38]. Additionally, both HTLV-3 and HTLV 4 were discovered in Cameroun [39] which shares boundary, some cultural and geographical similarities with north-eastern Nigeria where this study was carried out. There is no existing literature on either HTLV-3 or HTLV-4 from north-eastern Nigeria. Both HTLV-3 and HTLV-4 have currently not been associated with any human disease [39] and it is very likely to find them among apparently healthy adults such as prospective blood donors.

More than half of the studies on HTLV carried out in Nigeria utilized only ELISA or other antibody detection methods as means of identifying the virus (Table 3) [40-49]. This has shown that many of the studies done in Nigeria are without confirmatory tests thereby leaving

Table 3: HTLV in Nigeria

\begin{tabular}{|c|c|c|}
\hline Author Year Area & Method of Testing & Findings \\
\hline $\begin{array}{l}\text { Fleming et al. [16] } 1986 \\
\text { Nationwide }\end{array}$ & $\begin{array}{l}\text { Antibody detection } \\
\text { (Not specified) }\end{array}$ & $3.6 \%$ (North), $1.8 \%$ (Lagos) \& $0.7 \%$ (Calabar) among blood donors \\
\hline Williams et al. [14] 1993 Ibadan & ELISA and WB & $11 \%$ among blood donors \\
\hline $\begin{array}{l}\text { Olaleye et al. [40] } 1994 \\
\text { Nationwide }\end{array}$ & ELISA only & $\begin{array}{l}5.6 \% \text { overall, o.8\% (children), } 1.7 \% \text { (adolescents), } 16.3 \% \text { (STD } \\
\text { patients), } 8.3 \% \text { (Prostitutes), } 6.4 \text { (TB patients) and 3.3\% (HCW) }\end{array}$ \\
\hline Olaleye et al. [41] 1996 Ibadan & ELISA and PCR & $\begin{array}{l}5.4 \% \text { overall, } 15 \% \text { (patients with STDs) \& } 1.5 \% \text { (patients with } \\
\text { leukaemia/Lymphoma) }\end{array}$ \\
\hline Olaleye et al. [42] 1999 Ibadan & ELISA only & $4.3 \%$ among mothers and $1.1 \%$ among their children \\
\hline
\end{tabular}


Table 3: (Continued)

\begin{tabular}{|c|c|c|}
\hline $\begin{array}{l}\text { Forbi JC and 2007 Ibadan } \\
\text { Odetunde A [24] }\end{array}$ & ELISA only & $\begin{array}{l}5.1 \% \text { (secondary school students), } 16.1 \% \text {, (pregnant women) and } \\
22.9 \% \text { (CSW) }\end{array}$ \\
\hline $\begin{array}{l}\text { Olusanya et al. [43] } 1990 \text { Ogun } \\
\text { state }\end{array}$ & $\begin{array}{l}\text { Antibody detection } \\
\text { (Not specified) }\end{array}$ & 0.0052\% (healthy employees) \\
\hline Terry et al. [15] 2011 Osogbo & ELISA and WB & $3.6 \%$ among blood donors \\
\hline Analo et al. [44] 1998 Lagos & ELISA only & $0.7 \%$ among blood donors \\
\hline $\begin{array}{l}\text { Okpara et al. [45] } 1988 \text { Cross- } \\
\text { rivers }\end{array}$ & $\begin{array}{l}\text { Antibody detection } \\
\text { (Not specified) }\end{array}$ & 0.79\% among blood donors \\
\hline Durojaiye et al. [46] 2014 Lagos & ELISA and WB & $1 . \%$ by ELISA and $0.5 \%$ by WB among blood donors \\
\hline Okoye et al. [20] 2014 Enugu & ELISA only & $0.5 \%$ among pregnant women \\
\hline Akinbami et al. [47] 2014 Lagos & ELISA and WB & 5.1\% among patients with lymphoid malignancies \\
\hline $\begin{array}{l}\text { Oladipo et al. [48] } 2015 \\
\text { Ogbomoso }\end{array}$ & ELISA only & $25.8 \%$ among blood donors \\
\hline Okoye et al. [19] 2015 Enugu & ELISA only & o\% among blood donors \\
\hline Opaleye et al. [49] 2015 Osogbo & ELISA only & $24.2 \%$ among pregnant women \\
\hline
\end{tabular}

Abbreviations: ELISA Enzyme Linked Immunosorbent Assay

the possibility of having some false positive results among them.

\section{CONCLUSION}

The human $\mathrm{T}$ cell lymphotropic virus (HTLV) seroprevalence of $6.5 \%$ in this study which all turned out negative by western blot, further buttresses the need for confirmatory testing in HTLV research works. There is need to conduct a larger and community based research study on HTLV (including HTLV-3 and HTLV-4) in Gombe Nigeria. Comparative analysis of HTLV ELISA positive results with malaria testing will also help in revealing some possible explanations to the false positive ELISA in this malaria endemic zone. Routine screening of HTLV among prospective blood donors may possibly only be implemented based on regional realities from sound research works across the country because of size and geographical/socio-cultural variations in Nigeria.

\section{SUPPLEMENTARY INFORMATION}

Supplementary Information is available online at the journal's website.

\section{Acknowledgements}

We acknowledge the support and contributions from other members of staff of the Hematology department FTHG and Medical Microbiology department UCH Ibadan.

\section{Author Contributions}

Mohammed Mohammed Manga - Substantial contributions to conception and design, Acquisition of data, Analysis and interpretation of data, Drafting the article, Revising it critically for important intellectual content, Final approval of the version to be published Adeola Fowotade, Yuguda Saleh - Substantial contributions to conception and design, Acquisition of data, Analysis and interpretation of data, Drafting the article, Revising it critically for important intellectual content, Final approval of the version to be published Saleh Yuguda - Substantial contributions to conception and design, Acquisition of data, Revising it critically for important intellectual content, Final approval of the version to be published

Girei Ahmed Iya - Acquisition of data, Revising it critically for important intellectual content, Final approval of the version to be published

Mohammed Yahaya - Analysis and interpretation of data, Drafting the article, Final approval of the version to be published 
Yakubu Munkaila Sheriff - Acquisition of data, Revising it critically for important intellectual content, Final approval of the version to be published

Omoruyi Ewean Chukwuma - Acquisition of data, Revising it critically for important intellectual content, Final approval of the version to be published

Ibrahim Musa Yola - Analysis and interpretation of data, Revising it critically for important intellectual content, Final approval of the version to be published

Rasheed Ajani Bakare - Substantial contributions to conception and design, Revising it critically for important intellectual content, Final approval of the version to be published

\section{Guarantor}

The corresponding author is the guarantor of submission.

\section{Conflict of Interest}

Authors declare no conflict of interest.

\section{Copyright}

(C) 2016 Mohammed Mohammed Manga et al. This article is distributed under the terms of Creative Commons Attribution License which permits unrestricted use, distribution and reproduction in any medium provided the original author(s) and original publisher are properly credited. Please see the copyright policy on the journal website for more information.

\section{REFERENCES}

1. Gessain A, Cassar O. Epidemiological Aspects and World Distribution of HTLV-1 Infection. Front Microbiol 2012 Nov 15;3:388.

2. Gessain A, Cassar O. The Prevalence and Significance of HTLV-I/II Seroindeterminate Western Blot Patterns. Viruses 2011 Aug;3(8):1320-31.

3. Gonçalves DU, Proietti FA, Ribas JG, et al. Epidemiology, treatment, and prevention of human T-cell leukemia virus type 1-associated diseases. Clin Microbiol Rev 2010 Jul;23(3):577-89.

4. Arisawa K, Soda M, Endo S, et al. Evaluation of adult T-cell leukemia/lymphoma incidence and its impact on non-Hodgkin lymphoma incidence in southwestern Japan. Int J Cancer 2000 Feb 1;85(3):319-24.

5. Iwanaga M, Watanabe T, Yamaguchi K. Adult T-cell leukemia: a review of epidemiological evidence. Front Microbiol 2012;10;(3):322.

6. Rende F, Cavallari I, Romanelli MG, Diani E, Bertazzoni U, Ciminale V. Comparison of the Genetic Organization, Expression Strategies and Oncogenic Potential of HTLV-1 and HTLV-2. Leuk Res Treatment 2012:876153.

7. Bloch EM, Vermeulen M, Murphy E. Blood transfusion safety in Africa: a literature review of infectious disease and organizational challenges. Transfus Med Rev 2012;26(2):164-80.

8. Karimi G, Gharehbaghian A, Tafti MF, Vafaiyan V. Emerging infectious threats to the blood supply: seroepidemiological studies in iran - a review.
Transfus Med Hemother 2013 Jun;40(3):210-7.

9. Okochi K, Sato H, Hinuma Y. A retrospective study on transmission of adult $\mathrm{T}$ cell leukemia virus by blood transfusion: seroconversion in recipients. Vox Sang 1984;46(5):245-53.

10. Gout O, Baulac M, Gessain A, et al. Rapid development of myelopathy after HTLV-I infection acquired by transfusion during cardiac transplantation. N Engl J Med 1990;322(6):383-8.

11. Chen YC, Wang $\mathrm{CH}, \mathrm{Su} \mathrm{IJ}$, et al. Infection of human T-cell leukemia virus type I and development of human T-cell leukemia lymphoma in patients with hematologic neoplasms: a possible linkage to blood transfusion. Blood 1989;74(1):388-94.

12. deAlmeida Rego FF, Mota-Miranda A, de Souza Santos E, Galvão-Castro B, Alcantara LC. Seroprevalence and molecular epidemiology of HTLV-1 isolates from HIV-1 co-infected women in Feira de Santana, Bahia, Brazil. AIDS Res Hum Retroviruses 2010 Dec;26(12):1333-9.

13. Piot P, Quinn TC. Response to the AIDS pandemic--a global health model.N Engl J Med. 2013;368(23):2210-8.

14. Williams CK, Alexander SS, Bodner A, et al. Frequency of adult T-cell leukaemia/lymphoma and HTLV-I in Ibadan, Nigeria. Br J Cancer 1993;67(4):783-6.

15. Terry AA, Olusoga OD, Oluremi AS, Okanlawon BM, Uche LN, Muibi FA. Seroprevalence of HTLV -I/II amongst Blood Donors in Osogbo, Nigeria. Sudan J Med Sci 2011 6:177-82.

16. Fleming AF, Maharajan R, Abraham M, et al. Antibodies to HTLV-I in Nigerian blood-donors, their relatives and patients with leukaemias, lymphomas and other diseases. Int J Cancer 1986;38(6):809-13.

17. Advanced Laboratory Diagnostics. HTLV I \& II Ab. 2012. [Available at: https://www.diapro.it/index. php/products/micro-elisa/htlv-ab-detail]

18. MP Biomedicals. HTLV Blot 2.4. 2013. [Available at: http://www.mpbio.com/product. php?pid=0711080036\#tab-documents]

19. Okoye AE, Ibegbulam OG, Onoh RC, Ugwu NI, Anigbo CS, Nonyelu CE. Seroprevalence of human T-cell lymphoma/leukemia virus type-1 (HTLV-1) antibodies among blood donors at Enugu, Nigeria. J Blood Med 2015 Jan 19;6:31-6.

20. Okoye AE, Ibegbulam OG, Onoh RC, et al. Seroprevalence and correlates of human T-cell lymphoma/leukemia virus type 1 antibodies among pregnant women at the University of Nigeria Teaching Hospital, Enugu, Nigeria. Int J Womens Health 2014 Sep 18;6:849-5.

21. Olusanya O, Lawoko A, Blomberg J. Seroepidemiology of human retroviruses in Ogun State of Nigeria.Scand J Infect Dis 1990;22(2):155-60.

22. Diop S, Calattini S, Abah-Dakou J, Thiam D, Diakhaté L, Gessain A. Seroprevalence and molecular epidemiology of human T-Cell leukemia virus type 1 (HTLV-1) and HTLV-2 in blood donors from Dakar, Senegal. J Clin Microbiol 2006;44(4):1550-4.

23. da Silva ZJ, Nielsen J, Andersen A, et al. Decline in human T-cell lymphotropic virus-1 prevalence in urban areas of Bissau, Guinea-Bissau: exploring the association with HIV infections. AIDS 2009;23(5):637-9. 
24. Stramer SL, Notari EP, Zou S, et al. Human T-cell lymphotropic virus in a population of pregnant women and commercial sex workers in South Western Nigeria. Afr Health Sci 2007;7:129-32.

25. Stramer SL, Notari IV EP, Zou S, Krysztof DE, Brodsky JP, Tegtmeier GE, et al. Human T-lymphotropic virus antibody screening of blood donors: rates of falsepositive results and evaluation of a potential donor reentry algorithm. Transfusion 2011;51(4):692-701.

26. Szczypinska EM. Human T-Cell Lymphotrophic Viruses Workup. Medscape. 2012. [Available at: http://emedicine.medscape.com/article/219285workup]

27. León G, Quirós AM, López JL, et al. Seropositivity for human T-lymphotropic virus types I and II among donors at the Municipal Blood Bank of Caracas and associated risk factors. Rev Panam Salud Publica 2003;13(2-3):117-23.

28. Sertöz R, Turhan A, Bozkurt H, et al. Investigation of anti-HTLV I/II seroprevalence in healthy blood donors in Izmir region, Turkey. Mikrobiyol Bul 2010;44(4):579-84.

29. Hayes CG, Burans JP, Oberst RB. Antibodies to human $\mathrm{T}$ lymphotropic virus type $\mathrm{I}$ in a population from the Philippines: evidence for cross-reactivity with Plasmodium falciparum. $J$ Infect Dis 1991;163(2):257-62.

30. Elm J, Desowitz R, Diwan A. Serological crossreactivities between the retroviruses HIV and HTLV-1 and the malaria parasite Plasmodium falciparum. P N G Med J 1998;41(1):15-22.

31. Nowicki MJ, Matsuoka L, Brucal D, et al. High seroprevalence of anti-HTLV-I/II antibodies among solid organ donors necessitates confirmatory testing. Transplantation 2006;82(9):1210-3.

32. Tsao KC, Chen GW, Huang CG, et al. False positive antibody results against human T-cell lymphotropic virus in patients with severe acute respiratory syndrome. J Med Virol 2005 Nov;77(3):331-6.

33. Centers for Disease Control and Prevention (CDC). False-positive serologic tests for human T-cell lymphotropic virus type I among blood donors following influenza vaccination, 1992. MMWR Morb Mortal Wkly Rep 1993;42(9):173-5.

34. Srivastava BI, Gonzales C, Loftus R, Fitzpatrick JE, Saxinger CW. Examination of HTLV-I ELISA-positive leukemia/lymphoma patients by western blotting gave mostly negative or indeterminate reaction. AIDS Res Hum Retroviruses 1990;6(5):617-27.

35. Larocque É, Halin M, Landry S, Marriott SJ, Switzer WM, Barbeau B. Human T-Cell Lymphotropic Virus Type 3 (HTLV-3) and HTLV-4-Derived Antisense Transcripts Encode Proteins with Similar TaxInhibiting Functions but Distinct Subcellular Localization. J Virol 2011;85(23):12673-85.

36. Switzer WM, Hewlett I, Aaron L, Wolfe ND, Burke DS, Heneine W. Serologic testing for human T-lymphotropic virus-3 and -4.Transfusion. 2006 Sep;46(9):1647-8.

37. Calattini S, Chevalier SA, Duprez R, et al. Human T-cell lymphotropic virus type 3: complete nucleotide sequence and characterization of the human tax 3 protein. J Virol 2006;80(19):9876-88.
38. Calattini S, Chevalier SA, Duprez R, et al. Discovery of a new human T-cell lymphotropic virus (HTLV-3) in Central Africa. Retrovirology 2005 May 9;2:30.

39. Mahieux R, Gessain A. The human HTLV-3 and HTLV-4 retroviruses: new members of the HTLV family. Pathol Biol (Paris) 2009;57(2):161-6.

40. Olaleye DO, Bernstein L, Sheng Z, et al. Type-specific immune response to human $\mathrm{T}$ cell lymphotropic virus (HTLV) type I and type II infections in Nigeria. Am J Trop Med Hyg 1994;50(4):479-86.

41. Olaleye OD, Ekweozor CC, Li ZL, Opala IE, et al. Human T-cell lymphotropic virus types I and II infections in patients with leukaemia/lymphoma and in subjects with sexually transmitted diseases in Nigeria. Arch Virol 1996;141(2):345-55.

42. Olaleye DO, Omotade OO, Sheng Z, Adeyemo AA, Odaibo GN. Human T-cell lymphotropic virus types $\mathrm{I}$ and II infections in mother-child pairs in J Trop Pediatr 1999;45(2):66-70.

43. Olusanya O, Lawoko A, Blomberg J. Seroepidemiology of human retroviruses in Ogun State of Nigeria. Scand J Infect Dis 1990;22(2):155-60.

44. Analo HI, Akanmu AS, Akinsete I, Njoku OS, Okany CC. Seroprevalence study of HTLV-1 and HIV infection in blood donors and patients with lymphoid malignancies in Lagos, Nigeria. Cent Afr J Med 1998 May;44(5):130-4.

45. Okpara RA, Williams EE, Schneider J, Wendler I, Hunsmann G, HTLV-I antibodies in blood donors, patients with leukaemia, acute malaria and multiple blood transfusion recipients in the Cross River State of Nigeria. East Afr Med J 1988 Jul;65(7):495-502.

46. Durojaiye I, Akinbami A, Dosunmu A, et al. Seroprevalence of human $\mathrm{T}$ lymphotropic virus antibodies among healthy blood donors at a tertiary centre in Lagos, Nigeria. Pan Afr Med J 2014;17:301.

47. Akinbami A, Durojaiye I, Dosunmu A, et al. Seroprevalence of human T-lymphotropic virus antibodies among patients with lymphoid malignancies at a tertiary center in Lagos, Nigeria. J Blood Med 2014;5:169-74.

48. Oladipo EK, Akinpelu OO, Oladipo AA, et al. Human ? T Lymphotropic Virus 1 (HTLV-1) Among Blood Donors in Ogbomoso, Oyo State, Nigeria. Transl Med 2015;5.

49. Opaleye OO, Igboama MC, Ojo JA, Odewale G. Seroprevalence of HIV, HBV, HCV, and HTLV among Pregnant Women in Southwestern Nigeria. J Immunoassay Immunochem 2016;37(1):29-42. 
Access full text article on other devices

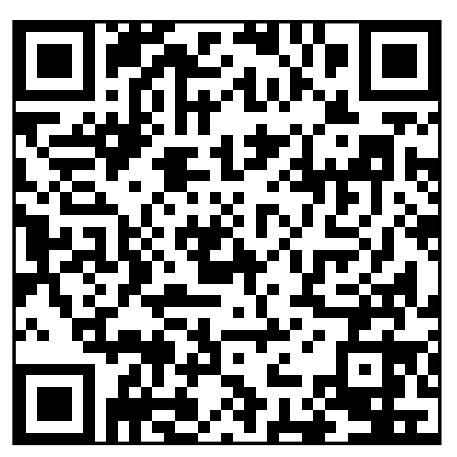

Access PDF of article on other devices

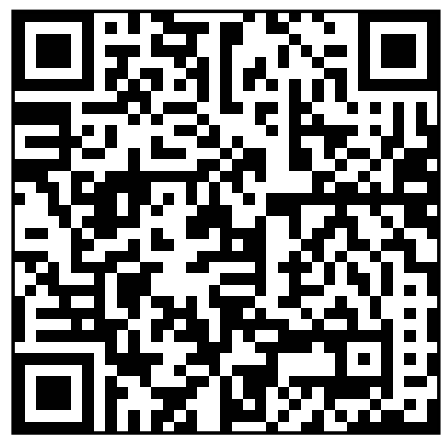

